\title{
Molecular Mapping of the New Blast Resistance Genes Pi47 and Pi48 in the Durably Resistant Local Rice Cultivar Xiangzi 3150
}

\author{
Hongmei Huang, Ling Huang, Guangping Feng, Suhua Wang, Yue Wang, Jinling Liu, Nan Jiang, \\ Weiting Yan, Lingchao Xu, Pingyong Sun, Zhiqiang Li, Sujun Pan, Xionglun Liu, \\ Yinghui Xiao, Erming Liu, Liangying Dai, and Guo-Liang Wang
}

First to seventeenth authors: Hunan Provincial Key Laboratory of Crop Gene Engineering, Hunan Agricultural University, Changsha 410128, China; and seventeenth author: Department of Plant Pathology, The Ohio State University, Columbus, Ohio 43210. First and second authors contributed equally to this project.

Accepted for publication 3 December 2010.

\begin{abstract}
Huang, H., Huang, L., Feng, G., Wang, S., Wang, Y., Liu, J., Jiang, N., Yan, W., Xu, L., Sun, P., Li, Z., Pan, S., Liu, X., Xiao, Y., Liu, E., Dai, L., and Wang, G.-L. 2011. Molecular mapping of the new blast resistance genes Pi47 and Pi48 in the durably resistant local rice cultivar Xiangzi 3150. Phytopathology 101:620-626.

The indica rice cultivar Xiangzi 3150 (XZ3150) confers a high level of resistance to $95 \%$ of the isolates of Magnaporthe oryzae (the agent of rice blast disease) collected in Hunan Province, China. To identify the resistance (R) gene(s) controlling the high level of resistance in this cultivar, we developed $286 \mathrm{~F}_{9}$ recombinant inbred lines (RILs) from a cross between XZ3150 and the highly susceptible cultivar CO39. Inoculation

polymorphic simple sequence repeat and single feature polymorphism markers was constructed with the genotype data of the 286 RILs. Composite interval mapping (CIM) using the results of 193-1-1 inoculation showed that two major R genes, designated Pi47 and Pi48, were located between RM206 and RM224 on chromosome 11, and between RM5364 and RM7102 on chromosome 12, respectively. Interestingly, the CIM analysis of the four resistant components of the RILs to the field blast population revealed that Pi47 and Pi48 were also the major genetic factors responsible for the field resistance in XZ3150. The DNA markers linked to the new R genes identified in this study should be useful for further fine mapping, gene cloning, and marker-aided breeding of blastresistant rice cultivars.
\end{abstract} of the RILs and an $\mathrm{F}_{2}$ population from a cross between the two cultivars with the avirulent isolate 193-1-1 in the growth chamber indicated the presence of two dominant R genes in XZ3150. A linkage map with 134
Additional keywords: Oryza sativa.
Rice blast, caused by the fungus Magnaporthe oryzae, is the most severe disease of rice (Oryza sativa L.) in many countries. This disease causes about 10 to $20 \%$ yield loss in regular seasons and as high as $100 \%$ yield loss in years with blast epidemics (5). Although the breeding of resistant rice varieties is an economical, effective, and environmentally responsible way to control the disease, newly released varieties planted in large areas frequently lose their resistance within a few years because of shifts in strains of the $M$. oryzae population. Another problem is that most of the major rice blast resistance $(\mathrm{R})$ genes thus far identified confer resistance to only a small set of blast isolates in a limited geographical region $(1,18)$.

Genetic studies of resistance to rice blast began when Goto established the differential system for $M$. oryzae races in Japan in the early 1960s (22). After the first molecular linkage map was published in 1988 (19), efforts to map resistance genes increased, especially once the rice genome was sequenced in $2002(7,30)$. To date, over 85 major rice blast $\mathrm{R}$ genes have been identified and mapped on rice chromosomes with molecular markers (1). Although these genes are located on all 12 chromosomes, many are clustered on chromosomes 6, 11, and 12 (1). Extensive efforts in the last 15 years have led to the cloning of $13 \mathrm{R}$ genes via map-

Corresponding authors: Y. Xiao: xiao_yh@yahoo.com.cn; E. Liu: emliu08@126.com; G.-L. Wang: wang.620@ osu.edu

* The $\boldsymbol{e}$-Xtra logo stands for "electronic extra" and indicates that the online version contains one supplemental figure.

doi:10.1094/PHYTO-08-10-0209

(c) 2011 The American Phytopathological Society based cloning strategies (18). Among the cloned genes, several confer high levels of resistance to diverse rice blast strains or races. For example, Pi2 confers resistance to 455 isolates collected from different regions of the Philippines and to most of the 792 isolates from the 13 major rice regions of China $(2,3,32)$. In a test with 43 isolates from 13 countries, a Pi9-carrying line was resistant to all isolates $(17,24)$. These two R genes (Pi2 and $\mathrm{Pi}$ ) have been used in the rice breeding programs in the last decade, and many new, highly resistant rice cultivars have been bred for rice production in China and several other Asian countries (18). Because the two genes are widely used in rice production, however, their resistance will gradually be lost with the emergence of virulent strains in the field. Although the new broad-spectrum resistance gene Pi40 was recently identified from $O$. australiensis, its durability to rice blast needs more field evaluations in different regions (11). Thus, identification of new broad-spectrum resistance genes is urgently needed for stable rice production.

Xiangzi 3150 (XZ3150), a local indica cultivar in Hunan Province, China, conferred resistance to $95 \%$ of the blast isolates collected from Jilin, Zhejiang, Hunan, Fujian, Guangdong, and Hainan Provinces, China (23). Previous genetic analysis showed that the resistance in XZ3150 to M. oryzae isolates was controlled by two major R genes, but the gene locations were not determined (16). This cultivar has been used in rice blast resistance breeding programs as a donor line for over 20 years. To understand the genetic basis of the broad-spectrum and stable resistance in XZ3150, in the current study we developed a recombinant inbred line (RIL) population from a cross between XZ3150 and the highly susceptible variety CO39. The resistance of the RILs was 
evaluated in both the growth chamber and the field. Two R genes, designated Pi47 and Pi48, were identified in XZ3150 and were mapped on chromosomes 11 and 12 , respectively.

\section{MATERIALS AND METHODS}

Development of the XZ3150/CO39 RILs. A cross was made between XZ3150 and the susceptible variety CO39, and the $F_{1}$ plants were selfed to produce $F_{2}$ seeds in Hunan, China. The single seed descend method was used from $\mathrm{F}_{2}$ to $\mathrm{F}_{9}$ generations. A total of $286 \mathrm{~F}_{9}$ RILs were obtained for blast inoculation and genotyping experiments.

Evaluation of blast disease severity in the growth chamber. M. oryzae 193-1-1 was isolated from the blast nursery in Taojiang County and belongs to the Chinese blast race ZC11 (23). It is one of the predominant strains in Taojiang and other regions of Hunan Province, and has stable virulence and sporulation capacity in the laboratory (unpublished data). The isolate was maintained on dry filter paper at $-20^{\circ} \mathrm{C}$. Actively growing mycelia of 193-1-1 from agar medium with tomato juice and oats were transferred to fresh medium and cultured for 5 days at $27^{\circ} \mathrm{C}$ under darkness, and then moved to an incubator with continuous fluorescent light at $27^{\circ} \mathrm{C}$ for another 5 days.

The $\mathrm{F}_{2}$ plant and $\mathrm{F}_{9}$ RIL inoculations were conducted in 2002 and 2009, respectively, in Changsha, China. Germinated seeds were sown in plastic trays $(30 \times 25 \times 5 \mathrm{~cm})$ in the greenhouse. Each tray contained 17 RILs, with 15 to 20 plants per RIL. CO39 and XZ3150 were included in each tray as the susceptible and resistant control, respectively. Seedlings at the three-to-four-leaf stage ( $\approx 18$ to 20 days after sowing) were sprayed with $50 \mathrm{ml}$ of a conidial suspension of isolate 193-1-1 $\left(\approx 1 \times 10^{5}\right.$ spores $/ \mathrm{ml}$ in $0.1 \%$ Tween 20) using a hand sprayer connected to an air compressor. The inoculated plants were sealed in plastic bags in the growth chamber at 26 to $28^{\circ} \mathrm{C}$. The plants were kept in the dark for $24 \mathrm{~h}$. The inoculated plants were subsequently kept in the same room with normal illumination (12 h light and $12 \mathrm{~h}$ dark) and high humidity (70 to $80 \%$ ) for an additional 6 days, at which time the susceptible check CO39 exhibited a highly susceptible reaction. The trays were maintained in plastic bags containing about $3 \mathrm{~cm}$ of water to keep the soil moist during the evaluation period. For each replication, 286 RILs and the susceptible and resistant controls were arranged in a completely randomized block design. Each line was inoculated three times. The inoculation for the entire RIL population was conducted during April and June 2009.

Disease severity on individual plants was evaluated with a 0 to 9 blast scoring system (9). $F_{2}$ plants with a score of 0 to 3 were considered resistant, and those with a score of 4 to 9 were considered susceptible. For each $\mathrm{F}_{9}$ RIL, the disease severity score was recorded as the average severity of 15 to 20 plants in each replication. The average disease severity score of each RIL in the growth chamber $\left(\mathrm{DS}_{\mathrm{G}}\right)$ was averaged from the three replications. Among the 286 RILs tested, only 251 lines with consistent resistant reaction in the three replications were used for the composite interval mapping (CIM).

Evaluation of rice blast disease severity in the field. A field experiment was conducted during April and August 2009, in the blast nursery of Taojiang County $\left(28^{\circ} 22^{\prime} \mathrm{N}\right.$ and $\left.112^{\circ} 03^{\prime} \mathrm{E}\right)$, Hunan Province, China. The blast nursery contained 11 major blast races, i.e., ZC9, ZC11, ZE3, ZB29, ZG1, ZB25, ZB31, ZB13, ZC7, ZA9, and ZF1 (unpublished data). The field contained clay soil. The blast infection was severe because there was only about $6 \mathrm{~h}$ of sunshine each day during the growing season and there are mountains to the north and south of the field. The humidity in the field was about 70 to $80 \%$ at night.

About $20 \mathrm{~F}_{9}$ seeds of the 286 RILs were sown in single-row plots, each row was $50 \mathrm{~cm}$ long. There were three replications for each line, and the plots were arranged in a completely randomized block design. The seedlings of all lines were separated by the susceptible spreader varieties Xiangaizao7 and Xiangwanxian11, which were planted in the middle of each block to enhance blast infection. The highly resistant XZ3150 and the highly susceptible CO39 were also seeded alternately in every 20 rows. Rice leaves infected with $M$. oryzae were obtained from other parts of the blast nursery. The leaves were cut into small sections $(\approx 2$ to $3 \mathrm{~cm})$ and were sprinkled over each plant of the susceptible spreader varieties to induce rice blast at the two-leaf stage.

The disease severity for individual plants in the field $\left(\mathrm{DS}_{\mathrm{F}}\right)$ was evaluated using a 0 to 9 blast scoring system (9). Lesion number (LN), percentage of diseased leaf area (DLA\%), and lesion size (LS) were determined 40 days after seeding. For each $\mathrm{F}_{9}$ RIL, the score of all resistance parameters was taken from five plants randomly selected in each plot. The final score of each RIL was the average score of three replications. Leaf area (LA) was determined using a portable area meter (ADC AM300, BioScientific Ltd., Herts, UK). DLA\% data were estimated according to Notteghem et al. (21). LS was calculated using the formula LS = $\mathrm{LA} \times \mathrm{DLA} \% / \mathrm{LN}$.

DNA extraction, parental polymorphism survey, and genotyping with molecular markers. The molecular marker analysis was conducted in Changhsha, China. Genomic DNA was extracted from the young leaves of each $\mathrm{F}_{9}$ RIL according to Saghai Maroof et al. (25). A total of 848 simple sequence repeat (SSR) and 66 single feature polymorphism (SFP) markers were used to survey the polymorphism between the two parents. The markers are evenly distributed on 12 rice chromosomes according to the results in Chen et al. (4), Temnykh et al. (26), McCouch et al. (20), the International Rice Genome Sequencing Project (8), and Jeremy et al. (10). The SSR marker assay was conducted as described by $\mathrm{Wu}$ and Tanksley (29). Polymerase chain reactions (PCRs) were conducted in a $10-\mu$ reaction mix containing $37.5 \mathrm{ng}$ of genomic DNA, $1 \times$ PCR buffer, 0.025 units of Taq DNA polymerase (TaKaRa Dalian Co., Dalian, China), $0.2 \mathrm{mmol}$ dNTPs, and 0.8 pmol forward and reverse primers. PCR amplification was performed with a PTC-200 thermal cycler (MJ Research Inc., Waltham, MA). The PCR reactions involved an initial denaturation at $94^{\circ} \mathrm{C}$ for $5 \mathrm{~min}$, followed by 35 cycles of denaturation for $30 \mathrm{~s}$ at $94^{\circ} \mathrm{C}$, annealing for $30 \mathrm{~s}$ at $55^{\circ} \mathrm{C}$, and extension for $1 \mathrm{~min}$ at $72^{\circ} \mathrm{C}$ and then a final extension for $7 \mathrm{~min}$ at $72^{\circ} \mathrm{C}$. DNA bands were visualized via silver staining on an $8 \%$ polyacrylamide gel.

Map construction and CIM analysis. A genetic linkage map was constructed from the genotypic data of the 286 RILs using Mapmaker version 3.0 software (14). The map distance was calculated based on the Kosambi function. Quantitative trait loci (QTL) Cartographer version 2.5 (31) was used to identify R genes conferring blast resistance on the basis of CIM analysis. The percentage of total phenotypic variation explained by each locus and their additive effects were estimated by the same software. Tests were performed at every 2-cM interval on the linkage map, and cofactors were selected by forward/backward stepwise regression (model 6) in QTL Cartographer (31). The significance threshold for CIM was determined by 300 permutation tests. In this study, the threshold value of LOD was 4.0. The phenotypic variation explained by a QTL $\left(r^{2}\right)$ conditioned by the CIM cofactors included in the model was calculated at the most likely QTL position.

\section{RESULTS}

Reevaluation of the resistance spectrum of XZ3150. Because the resistance of XZ3150 to rice blast had not been evaluated for about 15 years (23), we inoculated the cultivar with 303 isolates, representing 30 races of $M$. oryzae; these isolates had been recently collected from different regions of Hunan Province. Inoculation experiments showed that XZ3150 was resistant to $95.4 \%$ of 
the 303 isolates and was highly resistant to several predominant races in Hunan Province, including ZG1, ZB13, and ZC11 (Table 1).

Polymorphism survey of SSR and SFP markers. Among the 914 markers (848 SSRs and 66 SFPs) tested, 202 SSR and 20 SFP markers showed polymorphism between the two parents. A total of 134 codominant and reliable polymorphic markers evenly distributed on the 12 chromosomes were selected for the construction of a linkage map with the genotype data of the 286 RILs. Based on the Kosambi function, the linkage map consisting of 12 chromosomes was $2,085.8 \mathrm{cM}$ long with an average distance of $15.56 \mathrm{cM}$ between adjacent markers.

Identification and mapping of two $R$ genes in XZ3150. Among the $378 \mathrm{~F}_{2}$ plants inoculated with isolate 193-1-1 in the growth chamber, 351 plants were highly resistant (as resistant as XZ3150) and 27 plants were highly susceptible (as susceptible as
CO39). The segregation of resistant and susceptible plants fit a 15:1 ratio (Table $2, \chi^{2}=0.51<\chi_{0.05}^{2}=3.84$ ), indicating that XZ3150 carried two dominant $\mathrm{R}$ genes conferring resistance to 193-1-1.

A total of 251 RILs were inoculated with isolate 193-1-1 in the growth chamber. Among them, 182 RILs were highly resistant and 69 RILs were highly susceptible to the local blast population based on the 0 to 9 blast scoring system. The numbers of resistant and susceptible lines fit a 3:1 ratio (Table $2, \chi^{2}=0.83<\chi_{0.05}^{2}=$ 3.84 ), suggesting that two independent R loci in XZ3150 confer resistance to 193-1-1.

To map these two $\mathrm{R}$ genes, we performed CIM analysis using the marker genotype and resistance phenotype data of the 251 RILs. This analysis detected two genomic region with large LOD scores, one on chromosome 11 and one on chromosome 12 (Fig. 1). The locus on chromosome 11 was designated Pi47, and the

TABLE 1. Evaluation of the resistance spectrum of Xiangzi 3150

\begin{tabular}{|c|c|c|c|c|c|}
\hline Race group & Race & No. of isolates & Isolate origin in Hunan Province, $\mathrm{China}^{\mathrm{a}}$ & $\begin{array}{l}\text { No. of incompatible } \\
\text { isolates }\end{array}$ & $\begin{array}{c}\text { Resistance } \\
\text { frequency }(\%)\end{array}$ \\
\hline \multirow[t]{10}{*}{$\mathrm{ZA}$} & $\mathrm{ZA}_{1}$ & 5 & Taojiang & 5 & 100 \\
\hline & $\mathrm{ZA}_{3}$ & 2 & Xinning & 2 & 100 \\
\hline & $\mathrm{ZA}_{9}$ & 3 & Xinning (1), Suining (1), Taojiang (1) & 3 & 100 \\
\hline & $\mathrm{ZA}_{11}$ & 2 & Xinning (1), Yanxi (1) & 1 & 50 \\
\hline & $\mathrm{ZA}_{13}$ & 2 & Taojiang & 2 & 100 \\
\hline & $\mathrm{ZA}_{15}$ & 1 & Taojiang & 1 & 100 \\
\hline & $\mathrm{ZA}_{27}$ & 1 & Suining & 1 & 100 \\
\hline & $\mathrm{ZA}_{43}$ & 1 & Yanxi & 1 & 100 \\
\hline & $\mathrm{ZA}_{57}$ & 2 & Taojiang & 2 & 100 \\
\hline & $\mathrm{ZA}_{59}$ & 1 & Yanxi & 1 & 100 \\
\hline \multirow[t]{15}{*}{ ZB } & $\mathrm{ZB}_{1}$ & 11 & Suining (6), Yanxi (4), Guidong (1) & 11 & 100 \\
\hline & $\mathrm{ZB}_{3}$ & 4 & Yanxi (3), Guidong (1) & 4 & 100 \\
\hline & $\mathrm{ZB}_{5}$ & 1 & Taojiang & 1 & 100 \\
\hline & $\mathrm{ZB}_{7}$ & 4 & Daweishan (2), Taojiang (2) & 4 & 100 \\
\hline & $\mathrm{ZB}_{9}$ & 6 & Taojiang (2), Yanxi (4) & 6 & 100 \\
\hline & $\mathrm{ZB}_{11}$ & 3 & Taojiang & 3 & 100 \\
\hline & $\mathrm{ZB}_{13}$ & 35 & Taojiang (13), Xinning (10), Guidong (12) & 35 & 100 \\
\hline & $\mathrm{ZB}_{15}$ & 24 & Yanxi (12), Qidong (6), Chaling (6) & 21 & 87.5 \\
\hline & $\mathrm{ZB}_{17}$ & 1 & Taojiang & 1 & 100 \\
\hline & $\mathrm{ZB}_{21}$ & 1 & Daweishan & 1 & 100 \\
\hline & $\mathrm{ZB}_{23}$ & 1 & Daweishan & 1 & 100 \\
\hline & $\mathrm{ZB}_{25}$ & 3 & Taojiang (1), Yanxi (1), Daweishan (1) & 2 & 66.67 \\
\hline & $\mathrm{ZB}_{27}$ & 3 & Taojiang (1), Guidong (1), Daweishan (1) & 3 & 100 \\
\hline & $\mathrm{ZB}_{29}$ & 31 & Taojiang (11), Daweishan (20) & 30 & 96.77 \\
\hline & $\mathrm{ZB}_{31}$ & 13 & Taojiang (8), Daweishan (5) & 12 & 92.31 \\
\hline \multirow[t]{8}{*}{$\mathrm{ZC}$} & $\mathrm{ZC}_{1}$ & 1 & Daweishan & 1 & 100 \\
\hline & $\mathrm{ZC}_{3}$ & 3 & Yanxi (1), Qidong (1), Taojiang (1) & 3 & 100 \\
\hline & $\mathrm{ZC}_{5}$ & 1 & Taojiang & 1 & 100 \\
\hline & $\mathrm{ZC}_{7}$ & 1 & Xinning & 1 & 100 \\
\hline & $\mathrm{ZC}_{9}$ & 2 & Taojiang & 1 & 50 \\
\hline & $\mathrm{ZC}_{11}$ & 7 & Yuanjiang (3), Taojiang (2), Taoyuan (1), Qidong (1) & 7 & 100 \\
\hline & $\mathrm{ZC}_{13}$ & 10 & Qidong (3), Daweishan (7) & 9 & 90 \\
\hline & $\mathrm{ZC}_{15}$ & 10 & Jianghua (3), Guidong (2), Yizhang (2), Suining (2), Taoyuan (1) & 9 & 90 \\
\hline \multirow[t]{4}{*}{$\mathrm{ZD}$} & $\mathrm{ZD}_{1}$ & 8 & Daweishan (4), Yanxi (2), Taojiang (2) & 8 & 100 \\
\hline & $\mathrm{ZD}_{3}$ & 4 & Daweishan (1), Suining (3) & 3 & 75 \\
\hline & $\mathrm{ZD}_{5}$ & 2 & Daweishan & 2 & 100 \\
\hline & $\mathrm{ZD}_{7}$ & 4 & Daweishan (3), Taoyuan (1) & 4 & 100 \\
\hline \multirow[t]{2}{*}{$\mathrm{ZE}$} & $\mathrm{ZE}_{1}$ & 11 & Yanxi (3), Daweishan (5), Jianghua (3) & 11 & 100 \\
\hline & $\mathrm{ZE}_{3}$ & 12 & Qidong (3), Taojiang (1), Junshan (2), Jianghua (5), Daweishan (1) & 10 & 83.33 \\
\hline $\mathrm{ZF}$ & $\mathrm{ZF}_{1}$ & 13 & Daweishan (8), Jianghua (3), Taojiang (2) & 12 & 92.31 \\
\hline ZG & $\mathrm{ZG}_{1}$ & 53 & $\begin{array}{l}\text { Taojiang (16), Daweishan (15), Yanxi (7), Jianghua (5), Xinning (3), } \\
\text { Dongshan (3), Xinhua (1), Dongjiao (1), Suining (1), Yizhang (1) }\end{array}$ & 53 & 100 \\
\hline
\end{tabular}

${ }^{a}$ Numbers in parentheses indicate the umber of isolates from the region.

TABLE 2. Segregation of the resistant and susceptible plants or lines in $\mathrm{F}_{2}$ generation or $\mathrm{F}_{9}$ recombinant inbred lines after inoculation with Magnaporthe oryzae isolate 193-1-1 in the growth chamber

\begin{tabular}{|c|c|c|c|c|c|}
\hline \multirow[b]{2}{*}{ Generation } & \multicolumn{2}{|c|}{ No. of plants or lines } & \multicolumn{2}{|c|}{ Ratio of resistant to susceptible plants or lines } & \multirow{2}{*}{$\frac{\chi^{2} \text { for } 15: 1 \text { or } 3: 1}{\text { Ratio }}$} \\
\hline & Resistant & Susceptible & Observed & Expected & \\
\hline $\mathrm{F}_{2}$ & 351 & 27 & 13:1 & 15:1 & $0.51^{\mathrm{a}}$ \\
\hline $\mathrm{F}_{9}$ & 182 & 69 & 2.6:1 & $3: 1$ & $0.83^{\mathrm{a}}$ \\
\hline
\end{tabular}

a Not significant at the 0.05 level. 
locus on chromosome 12 was designated Pi48. The Pi47 region had a LOD score of 14.2 , explained $27.2 \%$ of the total phenotypic variation (Table 3), and was mapped between RM206 and RM224 (Fig. 1). Pi48 had a LOD score of 16.7, explained $22.5 \%$ of the total phenotypic variation, and was located in a 4.2-cM region between the SSR markers RM5364 and RM7102 and in a 0.2-cM region near the marker RM7102 (Table 3 ). The additive effects of the two $\mathrm{R}$ genes (resulting in improving the resistance) were derived from the XZ3150 alleles.

Major genetic factors for the blast resistance of XZ3150 in the field. To identify the QTL in XZ3150 for the M. oryzae population in the field, we evaluated the $\mathrm{DS}_{\mathrm{F}}, \mathrm{LN}, \mathrm{DLA} \%$, and LS of the 286 RILs and analyzed the data using the CIM method. The analysis showed that the two regions in chromosome 11 and 12, i.e., Pi47 and Pi48, were responsible for all four blast-resistant phenotypes in the field (Fig. 1). The peaks of the two regions closely overlapped with the regions of Pi47 and Pi48, which were identified in the inoculation with the isolate 193-1-1 in the growth chamber experiment (Fig. 1). The LOD score for the four resistant phenotypes at the Pi47 region ranged from 8 to 15 while those at the Pi48 region ranged from 7 to 18 . When the RILs carrying the two major genes were removed from the CIM analy- sis, no QTL with LOD scores over 3.0 were identified (data not shown), suggesting that the two $\mathrm{R}$ genes were the major contributors to XZ3150 blast resistance in the field.

To test the correlation between the number of $\mathrm{R}$ genes and disease resistance level among the RILs, we classified the RILs into three groups: those carrying both genes, those carry one gene, and those carry neither gene. Under both growth chamber and field conditions, the RILs with markers RM224 (linked to Pi47) and RM7102 (linked to Pi48) had significantly lower disease severity levels than the lines with the CO39 alleles at the loci. Disease severity level was negatively correlated with the number of R genes (Fig. 2). As the number of R genes in the RILs was increased, the $\mathrm{DS}_{\mathrm{G}}, \mathrm{DS}_{\mathrm{F}}, \mathrm{LN}, \mathrm{DLA} \%$, and LS were decreased. The correlation coefficients between the number of $\mathrm{R}$ genes and $\mathrm{DS}_{\mathrm{G}}, \mathrm{DS}_{\mathrm{F}}, \mathrm{LN}, \mathrm{DLA} \%$, and LS were $-0.909,-0.917$, $-0.894,-0.902$, and -0.947 , respectively.

Validation of the markers linked to the Pi47 and Pi48 genes. To validate the above mapping results, we selected three lines carrying the flanking markers of Pi47 but not those of Pi48, or carrying the flanking markers of Pi48 but not those of Pi47, for backcrossing with the susceptible parent CO39. The segregation ratio for resistant to susceptible plants in the derived $F_{2}$ popu-
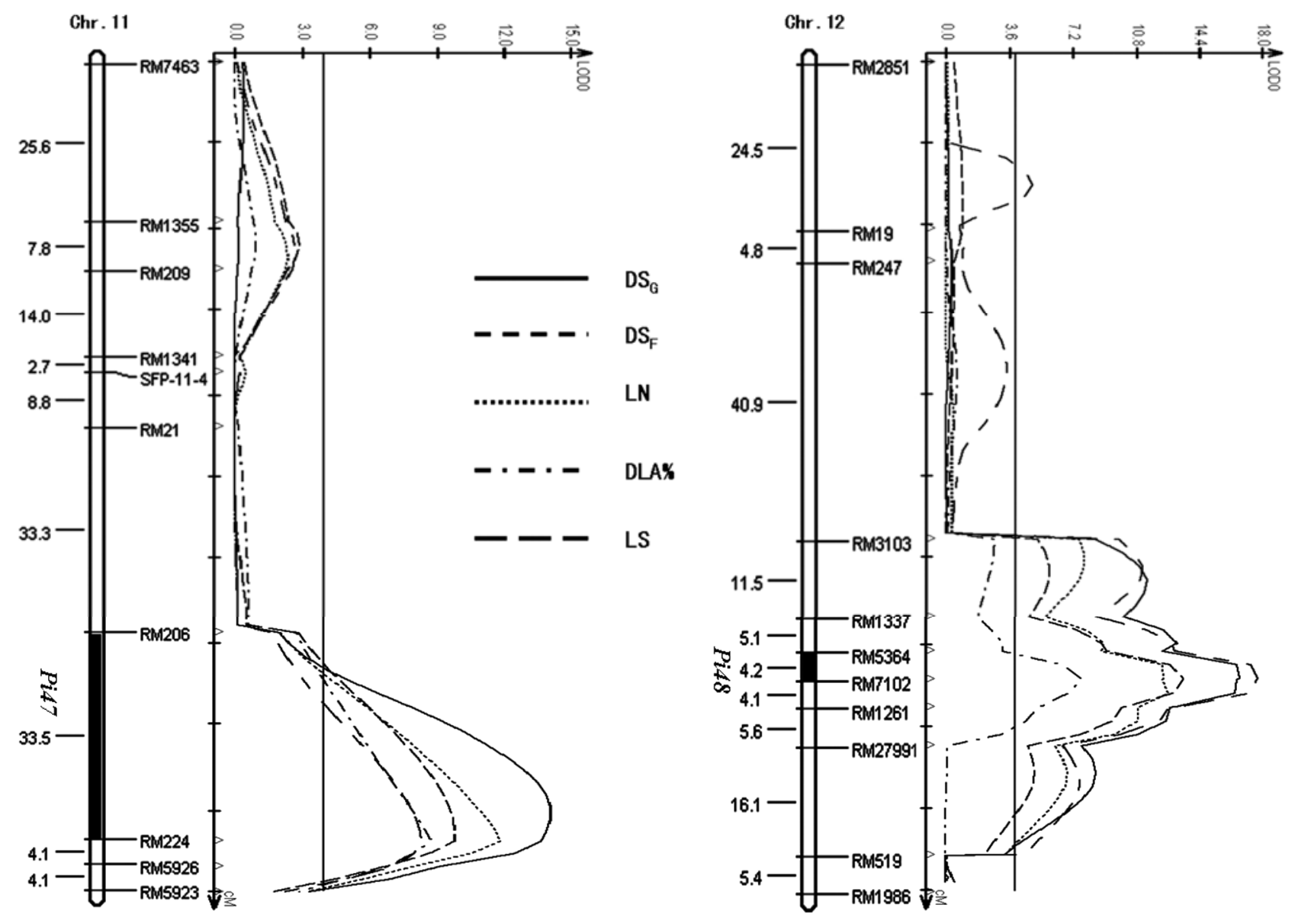

Fig. 1. Locations of the two resistance genes in Xiangzi 3150 to Magnaporthe oryzae isolate 193-1-1 in the growth chamber and to the M. oryzae population in the field. $\mathrm{DS}_{\mathrm{G}}$, disease severity in growth chamber; $\mathrm{DS}_{\mathrm{F}}$, disease severity in the field; LN, lesion number; DLA\%, percentage of diseased leaf area; and LS, lesion size.

TABLE 3. The chromosomal locations and additive effects of the Pi47 and Pi48 genes

\begin{tabular}{lcccccc}
\hline Gene & Chromosome & Marker interval & Distance $^{\mathrm{a}}(\mathrm{cM})$ & LOD score & $r^{2 \mathrm{~b}}$ & Additive $^{\mathrm{c}}$ \\
\hline Pi47 & 11 & RM206-RM224 & 5.5 & 14.15 & 0.2716 & -1.0658 \\
Pi48 & 12 & RM5364-RM7102 & 0.2 & 16.76 & 0.2253 & -0.9675 \\
\hline
\end{tabular}

${ }^{a}$ Refers to the distance of the gene to the nearest marker.

${ }^{\mathrm{b}}$ Refers to the percentage of phenotypic variation explained by a single gene.

${ }^{c}$ Refers to the additive effect of the XZ3150 alleles in increasing disease severity for individual plants in growth chamber or in field 
lations fit a 3:1 ratio, suggesting that there is a single resistant gene in these lines (data not shown). Molecular analysis confirmed that the flanking markers of Pi47 were linked to the resistance in the Pi47-carrying RILs and that the flanking markers of Pi48 were linked to the resistance in the Pi48-carrying RILs.

The SSR markers RM224 and RM7102, which are the nearest markers linked to Pi47 and Pi48, respectively, were used to select candidate RILs for resistance spectrum tests. Six RILs each for Pi47 and Pi48 were selected for resistance spectrum evaluation against 14 XZ3150 incompatible isolates (Table 4). The inoculations revealed that $P i 48$ conferred resistant to more isolates than Pi47, suggesting that Pi48 may has a broader resistance spectrum than Pi47.

\section{DISCUSSION}

Developing rice cultivars with broad-spectrum and durable resistance to rice blast has been a daunting challenge for rice breeders. One of the difficulties is the lack of $\mathrm{R}$ genes that are effective against many $M$. oryzae strains in different geographic regions. Among the 85 identified blast $\mathrm{R}$ genes, most confer resistance to only a few strains and have not been widely used in breeding programs. Although several durably blast-resistant cultivars have been reported, the genetic mechanism of the resistance in these cultivars has not been elucidated. Wang et al. (27) pioneered the use of RIL population to dissect the durable resistance in the upland rice cultivar Moroberekan. In that study, two major genes, Pi5 and Pi7, and over 10 QTL were identified. The authors concluded that durable resistance in Moroberekan is due to the combination of both major genes and QTL. One of the major genes, Pi5, was recently cloned via a map-based cloning strategy (12). Interestingly, the Pi5-mediated broad-spectrum resistance requires two nucleotide binding site-leucine-rich repeat genes, suggesting a novel defense strategy against blast infection in these rice plants. Similarly, Wu et al. (28) identified Pi25, Pi26, and eight QTL from the durably resistant cultivar Gumei 2, and Lee et al. (13) identified both Pi42 and Pi43 from the known blast-resistant cultivar Zhe733 using the KBNTlpa1-1 $\times$ Zhe733 RILs. In this study, we developed a set of $286 \mathrm{~F}_{9}$ RILs to identify the R genes in XZ3150 against a single isolate in the growth chamber and multiple isolates in the field. Both Pi47 on chromosome 11 and Pi48 on chromosome 12 confer the resistance to

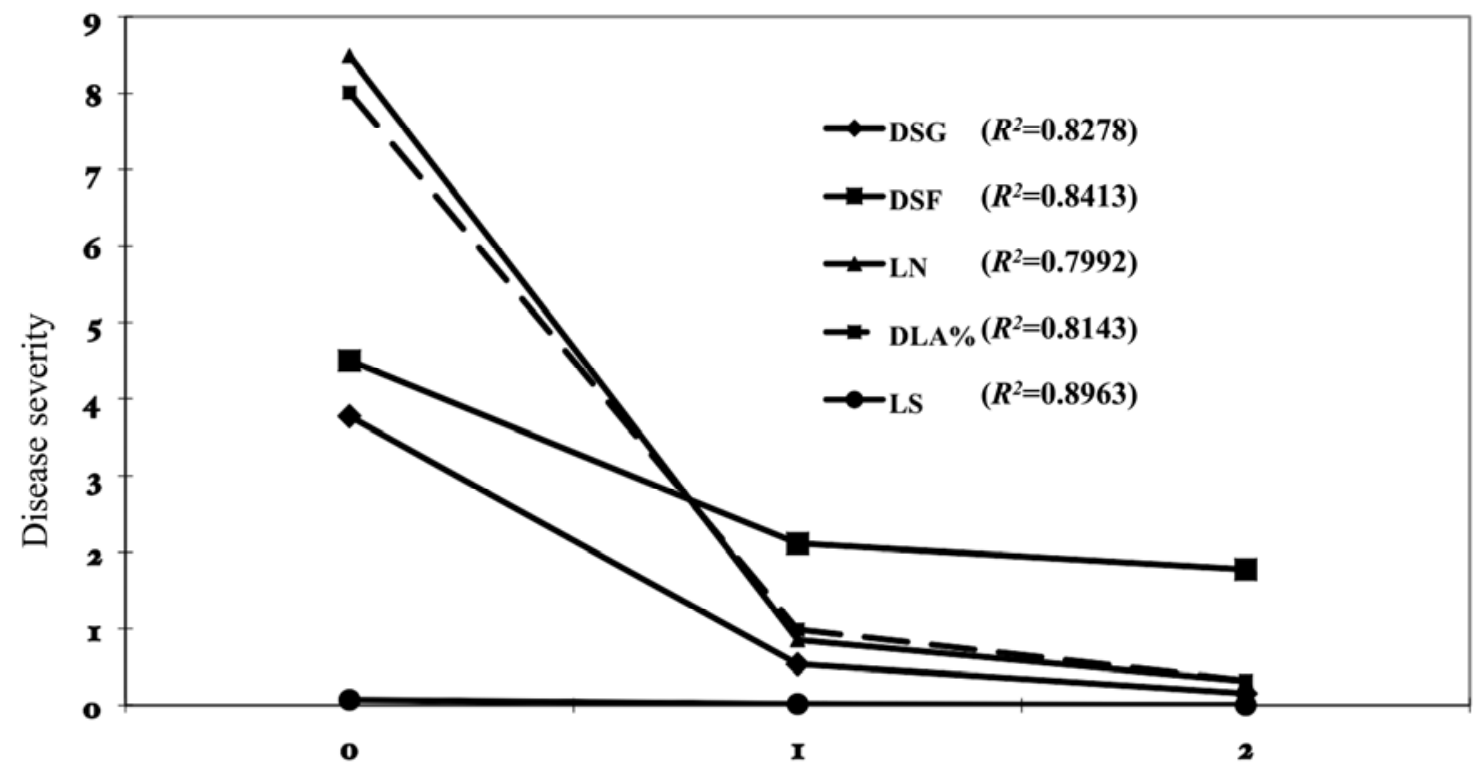

No. of resistance genes

Fig. 2. The correlation between the disease resistance level and number of resistance genes in the recombinant inbred lines under both growth chamber and field conditions.

TABLE 4. Reactions to several Magnaporthe oryzae isolates of recombinant inbred lines (RILs) determined from flanking marker data to contain Pi47 or Pi48 gene for rice blast resistance

\begin{tabular}{|c|c|c|c|c|c|c|c|c|c|c|c|c|c|c|c|c|}
\hline \multirow[b]{2}{*}{ Line } & \multicolumn{2}{|c|}{ Marker genotype } & \multicolumn{14}{|c|}{ Isolate } \\
\hline & $\begin{array}{l}\mathrm{RM} \\
224\end{array}$ & $\begin{array}{c}\text { RM } \\
7102\end{array}$ & $\begin{array}{c}\text { CHL } \\
645\end{array}$ & $\begin{array}{c}\text { CHL } \\
446\end{array}$ & $\begin{array}{l}\text { CHL } \\
1743\end{array}$ & $\begin{array}{c}\text { CHL } \\
440\end{array}$ & $\begin{array}{l}\text { e2007 } \\
046 \mathrm{~A} 2\end{array}$ & RB 6 & $\begin{array}{c}\text { CHL } \\
471\end{array}$ & $\begin{array}{c}\text { CHL } \\
506\end{array}$ & $\begin{array}{l}\text { CHL } \\
473\end{array}$ & 0901-2 & ES 6-1 & RB 14 & $0905-1$ & 0904-3 \\
\hline RIL005 & $\mathrm{C}$ & X & $\mathrm{R}$ & $\mathrm{R}$ & S & $\mathrm{R}$ & $\mathrm{R}$ & $\mathrm{R}$ & $\mathrm{R}$ & $\mathrm{R}$ & $\mathrm{R}$ & $\mathrm{R}$ & $\mathrm{R}$ & $\mathrm{R}$ & $\mathrm{S}$ & $\mathrm{R}$ \\
\hline RIL079 & $\mathrm{C}$ & $X$ & $\mathrm{R}$ & $\mathrm{R}$ & $\mathrm{S}$ & $\mathrm{R}$ & $\mathrm{R}$ & $\mathrm{R}$ & $\mathrm{R}$ & $\mathrm{R}$ & $\mathrm{R}$ & $\mathrm{R}$ & $\mathrm{R}$ & $\mathrm{R}$ & $\mathrm{R}$ & $\mathrm{R}$ \\
\hline RIL158 & $\mathrm{C}$ & $\mathrm{X}$ & $\mathrm{R}$ & $\mathrm{R}$ & $S$ & $\mathrm{R}$ & $\mathrm{R}$ & $\mathrm{R}$ & $\mathrm{S}$ & $\mathrm{R}$ & $\mathrm{R}$ & $\mathrm{R}$ & $\mathrm{R}$ & $\mathrm{R}$ & $\mathrm{R}$ & $\mathrm{R}$ \\
\hline RIL171 & $\mathrm{C}$ & $X$ & $\mathrm{R}$ & $\mathrm{R}$ & $\mathrm{S}$ & $\mathrm{R}$ & $\mathrm{R}$ & $\mathrm{R}$ & $\mathrm{R}$ & $\mathrm{R}$ & $\mathrm{R}$ & $\mathrm{R}$ & $\mathrm{R}$ & $\mathrm{R}$ & $\mathrm{R}$ & $\mathrm{R}$ \\
\hline RIL070 & $X$ & $\mathrm{C}$ & $\mathrm{R}$ & S & $\mathrm{R}$ & $\mathrm{R}$ & $\mathrm{R}$ & $\mathrm{R}$ & $\mathrm{R}$ & $\mathrm{R}$ & $\mathrm{R}$ & $\mathrm{R}$ & $\mathrm{R}$ & $\mathrm{R}$ & $\mathrm{S}$ & $\mathrm{R}$ \\
\hline RIL147 & X & $\mathrm{C}$ & $\mathrm{R}$ & $\mathrm{S}$ & $\mathrm{R}$ & $\mathrm{S}$ & $\mathrm{R}$ & $\mathrm{R}$ & $\mathrm{R}$ & $\mathrm{S}$ & $\mathrm{R}$ & $\mathrm{S}$ & $\mathrm{R}$ & $\mathrm{R}$ & $\mathrm{R}$ & $\mathrm{R}$ \\
\hline RIL230 & X & C & $\mathrm{S}$ & $\mathrm{S}$ & $\mathrm{R}$ & S & S & $\mathrm{R}$ & $\mathrm{R}$ & $\mathrm{R}$ & $\mathrm{R}$ & $\mathrm{R}$ & $\mathrm{R}$ & $\mathrm{R}$ & $\mathrm{R}$ & $\mathrm{R}$ \\
\hline RIL279 & $X$ & $\mathrm{C}$ & $\mathrm{S}$ & $\mathrm{S}$ & $\mathrm{S}$ & $\mathrm{S}$ & $\mathrm{S}$ & $\mathrm{R}$ & $\mathrm{R}$ & $\mathrm{R}$ & $\mathrm{R}$ & $\mathrm{R}$ & $\mathrm{R}$ & $\mathrm{R}$ & - & $\mathrm{R}$ \\
\hline
\end{tabular}

${ }^{a}$ The genotype of the nearest marker linked to the resistance gene. RM224 and RM7102 are the nearest markers linked to Pi47 and Pi48, respectively. C and X denote the CO39 and XZ3150 genotype at the linked marker, respectively. 
isolate 193-1-1 and to the M. oryzae population in the field. When the RILs carrying both $\mathrm{R}$ genes were removed from the data set for the CIM analysis, no significant QTL (LOD $\geq 3.0$ ) was identified, suggesting that these two R genes are largely responsible for the broad-spectrum resistance in XZ3150. How these two R genes control the high level of resistance in XZ3150 and the molecular mechanism of their defense to rice blast infection will be revealed once both genes are cloned and characterized.

At least $17 \mathrm{R}$ genes are mapped on chromosome 11, i.e., $P i-a$, Pi-f, Pi-k, Pik-h, Pik-m, Pi-1, Pi-7, Pi-12(t), Pi-18, Pi-34, Pi-38, $P i-43(t), P i-44(t), p b 1, P i-C O 39(t), P i-y(t)$, and Pi-zy(t) (1). Among them, $P i-43(t), P i-k$, and $P i k-h$ are linked to the marker RM224 (http://www.ricedata.cn/gene/gene_pi.htm). Pi-k is located between the SSR markers of RM1233 and RM224 on the long arm of chromosome 11 , with a distance of 1.6 and $0.2 \mathrm{cM}$ to the linked marker, respectively (http://www.ricedata.cn/gene/ gene_pi.htm). Pik- $h$ was mapped to a $2-\mathrm{cM}$ interval between RM224 and Y6855RA in the same region (http://www.ricedata.cn/ gene/gene_pi.htm). Pi43(t) from the rice variety Zhe733 is also tightly linked to RM1233 and RM224 (13). The Pi47 gene found in this study is located between RM206 and RM224. At least 16 $\mathrm{R}$ genes are located on rice chromosome 12 (1). Among them, only two are linked to the SSR marker RM7102 according to previous studies $(6,15)$. $P i$ - $t a^{2}$ was allelic to $P i$-ta (6) on chromosome 12, which is located outside of the marker interval of RM5364-RM7102. Pi-GD-3(t) is linked to the SSR marker of RM179 on chromosome 12 (15), outside of the interval of the RM5364-RM7102 region. The Pi48 gene identified in our study is novel because no gene has been previously reported in the same region on chromosome 12 . The exact physical location of the Pi47 and Pi48 genes and their relationship with known R genes in the same region will be revealed by fine-mapping of both genes. As shown in Table 4, the putative Pi47- or Pi48-carrying lines had different resistance reactions to the same isolates. This is because we selected them based on their linked marker genotypes. When near-isogenic lines of Pi47 and Pi48 in the CO39 background are obtained, more inoculations will be conducted to confirm the resistance spectrum of the two genes.

XZ3150 has maintained durable resistance to rice blast for over 20 years in Hunan Province and is being used in many rice breeding programs (23). Its poor agronomical traits (it produces low yields and often lodges), however, are difficult to eliminate by conventional backcross method in the progenies when it is crossed with an elite rice line. This problem has frustrated rice breeders who want to use XZ3150 in their breeding programs. The identification of the DNA markers linked to Pi47 and Pi48 in this study should allow rice breeders to efficiently transfer the resistance genes in XZ3150 into new, elite rice cultivars using marker-aided selection. Once new markers tightly linked to Pi47 and Pi48 are identified, PCR-based markers will be developed for rice blast resistance breeding.

\section{ACKNOWLEDGMENTS}

This research was supported by the State Key Development Program for Basic Research of China (Grant 2006CB101904), the Commonwealth Specialized Research Fund of China Agriculture (Grant 200803008), the National Natural Science Foundation of China (Grant 30871335 and 30828022), the Ph.D. Programs Foundation of Ministry of Education of China (Grant 20060537004), and the Scientific Research Fund of Hunan Provincial Education Department, China (Grant 06A029).

\section{LITERATURE CITED}

1. Ballini, E., Morel, J. B., Droc, G., Price, A., Courtois, B., Notteghem, J. L., and Tharreau, D. 2008. A genome-wide meta-analysis of rice blast resistance genes and quantitative trait loci provides new insights into partial and complete resistance. Mol. Plant-Microbe Interact. 21:859-868.

2. Chen, D. H., dela Vina, M., Inukai, T., Mackill, D. J., Ronald, P. C., and
Nelson, R. J. 1999. Molecular mapping of the blast resistance gene, $P i 44(t)$ in a line derived from a durably resistant rice cultivar. Theor. Appl. Genet. 98:1046-1053.

3. Chen, D. H., Zeigler, R. S., Ahn, S. W., and Nelson, R. J. 1996. Phenotypic characterization of the rice blast resistance gene Pi2(t). Plant Dis. 80:52-56.

4. Chen, X., Temnykh, S., Xu, Y., Cho, Y. G., and McCouch, S. R. 1997. Development of a microsatellite framework map providing genome-wide coverage in rice (Oryza sativa L.). Theor. Appl. Genet. 95:553-567.

5. Dean, R. A., Talbot, N. J., Ebbole, D. J., Farman, M. L., Mitchell, T. K., Orbach, M. J., Thon, M., Kulkarni, R., Xu, J. R., Pan, H., Read N. D., Lee, Y. H., Carbone, I., Brown, D., Oh, Y. Y., Donofrio, N., Jeong, J. S., Soanes, D. M., Djonovic, S., Kolomiets, E., Rehmeyer, C., Li, W., Harding, M., Kim, S., Lebrun, M. H., Bohnert, H., Coughlan, S., Butler, J., Calvo, S., Ma, L. J., Nicol, R., Purcell, S., Nusbaum, C., Galagan, J. E., and Birren, B. W 2005. The genome sequence of the rice blast fungus Magnaporthe grisea. Nature 434: 980-986.

6. Fjellstrom, R., Conaway-Bormans, C. A., McClung, A. M., Marchetti, M. A., Shank, R., and Park, W. D. 2004. Development of DNA markers suitable for marker assisted selection of three $P i$ genes conferring resistance to multiple Pyricularia grisea pathotypes. Crop Sci. 44:17901798.

7. Goff, S. A., Ricke, D., Lan, T. H., Presting, G., Wang, R., Dunn, M., Glazebrook, J., Sessions, A., Oeller, P., Varma, H., Hadley, D., Hutchison, D., Martin, C., Katagiri, F., Lange, B. M., Moughamer, T., Xia, Y., Budworth, P., Zhong, J., Miguel, T., Paszkowski, U., Zhang, S., Colbert, M., Sun, W. L., Chen, L., Cooper, B., Park, S., Wood, T. C., Mao, L., Quail, P., Wing, R., Dean, R., Yu, Y., Zharkikh, A., Shen, R., Sahasrabudhe, S., Thomas, A., Cannings, R., Gutin, A., Pruss, D., Reid, J., Tavtigian, S., Mitchell, J., Eldredge, G., Scholl, T., Miller, R. M., Bhatnagar, S., Adey, N., Rubano, T., Tusneem, N., Robinson, R., Feldhaus, J., Macalma, T., Oliphant, A., and Briggs, S. 2002. A draft sequence of the rice genome (Oryza sativa L. ssp. japonica). Science 296:92-100

8. International Rice Genome Sequencing Project. 2005. The map-based of the rice genome. Nature 436:793-800.

9. International Rice Research Institute. 1996. Standard Evaluation System for Rice. 4th ed. International Rice Research Institute, Manila, Philippines.

10. Jeremy, D. E., Jaroslav, J., Megan, T. S., Ambika, B. G., Liu, B., Hei, L., and David, W. G. 2008. Development and evaluation of a highthroughput, low-cost genotyping platform based on oligonucleotide microarrays in rice. Plant Methods 4:13.

11. Jeung, J. U., Kim, B. R., Cho, Y. C., Han, S. S., Moon, H. P., Lee, Y. T., and Jena, K. K. 2007. A novel gene, Pi4O(t), linked to the DNA markers derived from NBS-LRR motifs confers broad spectrum of blast resistance in rice. Theor. Appl. Genet. 115:1163-1177.

12. Lee, S., Song, M. Y., Seo, Y. S., Kim, H. K., Ko, S., Cao, P. J., Suh, J. P., Yi, G., Roh, J. H., Lee, S., An, G., Hahn, T. R., Wang, G. L., Ronald, P., and Jeon, J. S. 2009. Rice Pi5-mediated resistance to Magnaporthe oryzae requires the presence of two CC-NB-LRR genes. Genetics 181:1627-1638.

13. Lee, S., Wamishe, Y., Jia, Y., Liu, G., and Jia, M. H. 2009. Identification of two major resistance genes against race IE-1k of Magnaporthe Oryzae in the indica rice cultivar Zhe733. Mol. Breed. 24:127-134.

14. Lincoln, S., Daley, M., and Lander, E. 1992. Constructing genetic maps with MAPMAKER/EXP 3.0, 3rd ed. Whitehead Institute Technical Report, Cambridge.

15. Liu, B., Zhang, S. H., Zhu, X. Y., Yang, Q. Y., Wu, S. Z., Mei, M. T., Mauleon, R., Leach, J., Mew, T., and Leung, H. 2004. Candidate defense genes as predictors of quantitative blast resistance in rice. Mol. PlantMicrobe Interact. 17:1146-1152.

16. Liu, E. M., Peng, S. Q., Huang, F. Y., Xiao, F. H., and Li, D. X. 1998. Resistant inheritance of 3 rice varieties with durable resistance to rice blast disease. Plant Prot. 25:10-11. (In Chinese with English abstract)

17. Liu, G., Lu, G., Zeng, L., and Wang, G. L. 2002. Two broad-spectrum blast resistance genes, $P i 9(t)$ and $P i 2(t)$, are physically linked on rice chromosome 6. Mol. Genet. Genomics 267:472-480.

18. Liu, J. L., Wang, X. J., Mitchell, T., Hu, Y. J., Liu, X. L., Dai, L. Y., and Wang, G. L. 2010. Recent progress and understanding of the molecular mechanisms of the rice-Magnaporthe oryzae interaction. Mol. Plant Pathol. 11:419-427.

19. McCouch, S. R., Kochert, G., Yu, Z. H., Wang, Z. Y., Khush, G. S., Coffman, W. R., and Tanksley, S. D. 1988. Molecular mapping of rice chromosomes. Theor. Appl. Genet. 76:815-829.

20. McCouch, S. R., Teytelman, L., Xu, Y., Lobos, K. B., Clare, K., Walton, M., Fu, B., Maghirang, R., Li, Z., Xing, Y., Zhang, Q., Kono, I., Yano, M., Fjellstrom, R., DeClerck, G., Schneider, D., Cartinhour, S., Ware, D., and Stein, L. 2002. Development and mapping of 2240 new SSR markers for rice (Oryza sativa L.). DNA Res. 9:199-207.

21. Notteghem, J. L., Chatel, M., and Dechanet, R. 1981. Diallel analyze of 
two characteristics of rice resistance to Pyricularia oryzae. Pages 301-318 in: Comptes-rendus du symposium sur la resistance du riz a la pyriculariose. IRAT-GERDAT, Montpellier, France.

22. Ou, S. H. 1985. Pages 109-201 in: Rice Disease, 2nd ed. The Cambrian News Ltd., U.K.

23. Peng, S. Q., Liu, E. M., Huang, F. Y., Xiao, F. H., Fan, K. C., Luo, L. M., and Chen, Y. 1996. Research on durable resistance to rice blast disease. Acta Phytophylactica Sinica 23:293-299. (In Chinese with English abstract)

24. Qu, S. H., Liu, G. F., Zhou, B., Bellizzi, M., Zeng, L. R., Dai, L. Y., Han, B., and Wang, G. L. 2006. The broad-spectrum blast resistance gene Pi9 encodes a nucleotide- binding site-leucine-rich repeat protein and is a member of a multigene family in rice. Genetics 172:1901-1914.

25. Saghai Maroof, M. A., Biyashev, R. M., Yang, G. P., Zhang, Q., and Allard, R. W. 1994. Extraordinarily polymorphic microsatellite DNA in barley: Species diversity, chromosomal locations, and population dynamics. Proc. Nat. Acad. Sci. USA 91:5466-5470.

26. Temnykh, S., Park, W. D., Ayres, N., Cartinhour, S., Hauck, N., Lipovich, L., Cho, Y. G., Ishii, T., and McCouch, S. R. 2000. Mapping and genome organization of microsatellite sequences in rice (Oryza sativa L.). Theor. Appl. Genet. 100:697-712.

27. Wang, G. L., MacKill, D. J., Bonman, J. M., McCouch, S. R., Champoux, M., and Nelson, R. 1994. RFLP mapping of genes conferring complete and partial resistance to blast in a durably resistant rice cultivar. Genetics 136:1421-1434.

28. Wu, J. L., Fan, Y. Y., Li, D. B., Zheng, K. L., Leung, H., and Zhuang, J. Y.
2005. Genetic control of rice blast resistance in the durably resistant cultivar Gumei 2 against multiple isolates. Theor. Appl. Genet. 111:50-56.

29. Wu, K. S., and Tanksley, S. D. 1993. Abundance, polymorphism and genetic mapping of microsatellites in rice. Mol. Gen. Genet. 241:225-235.

30. Yu, J., Hu, S., Wang, J., Wong, G. K., Li, S., Liu, B., Deng, Y., Dai, L., Zhou, Y., Zhang, X., Cao. M., Liu, J., Sun, J., Tang, J., Chen, Y., Huang, X., Lin, W., Ye, C., Tong, W., Cong, L., Geng, J., Han, Y., Li, L., Li, W., Hu, G., Huang, X., Li, W., Li, J., Liu, Z., Li, L., Liu, J., Qi, Q., Liu, J., Li, L., Li, T., Wang, X., Lu, H., Wu, T., Zhu, M., Ni, P., Han, H., Dong, W., Ren, X., Feng, X., Cui, P., Li, X., Wang, H., Xu, X., Zhai, W., Xu, Z., Zhang, J., He, S., Zhang, J., Xu, J., Zhang, K., Zheng, X., Dong, J., Zeng, W., Tao, L., Ye, J., Tan, J., Ren, X., Chen, X., He, J., Liu, D., Tian, W., Tian, C., Xia, H., Bao, Q., Li, G., Gao, H., Cao, T., Wang, J., Zhao, W., Li, P., Chen, W., Wang, X., Zhang, Y., Hu, J., Wang, J., Liu, S., Yang, J., Zhang, G., Xiong, Y., Li, Z., Mao, L., Zhou, C., Zhu, Z., Chen, R., Hao, B., Zheng, W., Chen, S., Guo, W., Li, G., Liu, S., Tao, M., Wang, J., Zhu, L., Yuan, L., and Yang, H. 2002. A draft sequence of the rice genome (Oryza sativa L. ssp. indica). Science 296:79-92.

31. Zeng, Z. B. 1994. Precision mapping of quantitative trait loci. Genetics 136:1457-1468.

32. Zhou, B., Qu, S. H., Liu, G. F., Dolan, M., Sakai, H., Lu, G., Bellizzi, M., and Wang, G. L. 2006. The eight amino-acid differences within three leucine-rich repeats between $P i 2$ and $P i z-t$ resistance proteins determine the resistance specificity to Magnaporthe grisea. Mol. Plant-Microbe Interact. 19:1216-1228. 